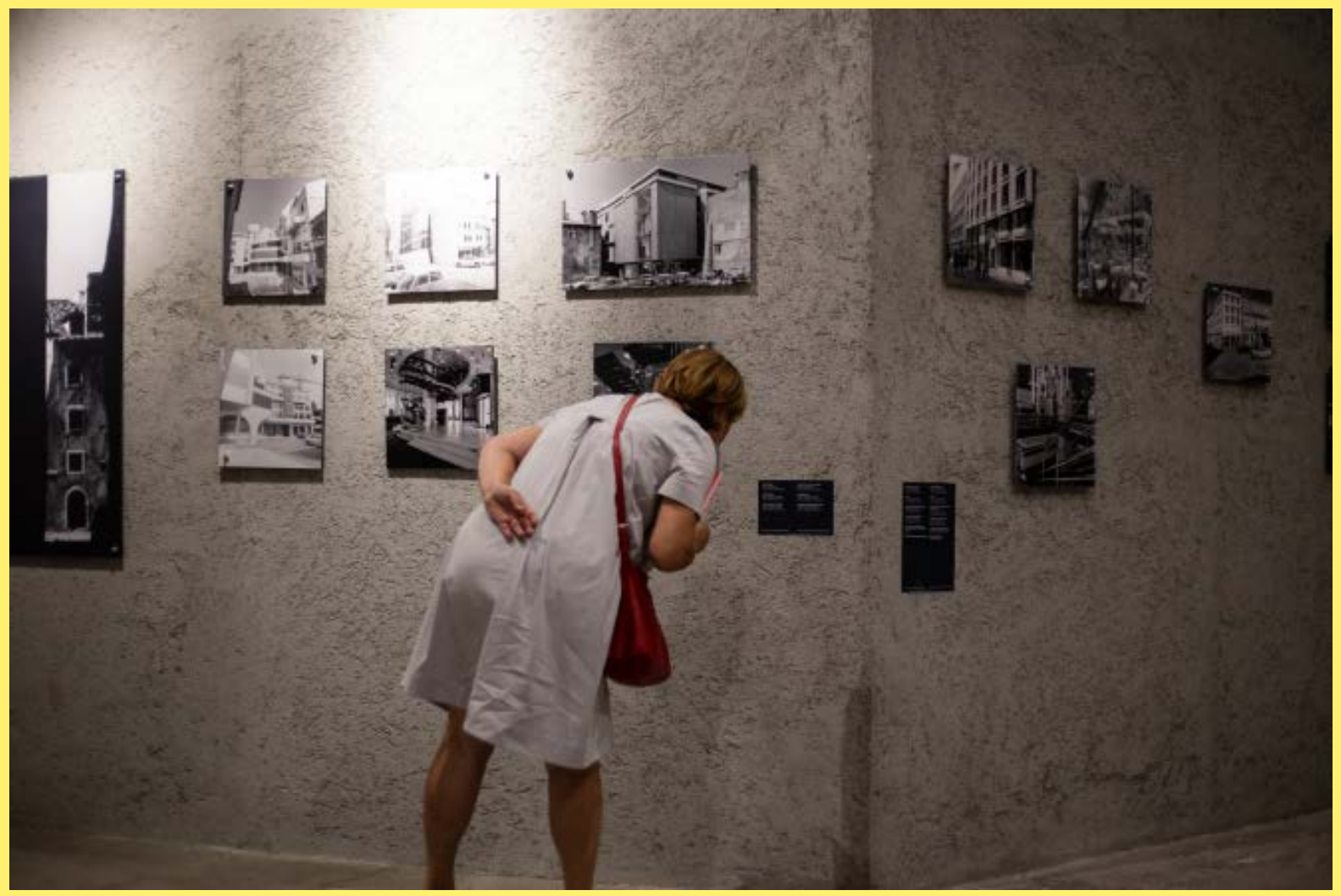

Izložba Fiume Fantastika: Fenomeni grada. Foto: Matija Kralj 


\section{OTVORENO PISMO MAURU SIROTNJAKU}

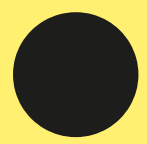

Venecija, 27. svibnja 2021.

Dragi Mauro,

pročitao sam tekst koji si napisao za Život umjetnosti, za koji ti se zahvaljujem. Za razliku od drugih, mene negativne kritike ne pogađaju toliko, jer sam izrastao u svijetu koji se bazirao na neposrednoj kritici. Ti nisi doživio luav devedesetih, i ne znaš koja je bila uloga kritike i konfrontacije u tadašnjoj školi. Ali baš u duhu te dijalektike, iz koje sam izrastao, uzimam si pravo i prostor da reagiram na tvoj tekst - „a caldo" - i da ti kažem što o njemu mislim. Sa specifikacijom da većina ideja koje čine izložbu i projekt DeltaLab-a nisu moje, već da sam sudjelovao, s iskrenim entuzijazmom, kao diskutant i istraživač samo u nekim specifičnim dijelovima i fazama ove skoro petogodišnje avanture.

Mislim da nisi shvatio dosta stvari. Mislim da je serija argumenata kojih si se primio kod gledanja na izložbu i na cijeli projekt DeltaLab-a površna, neutemeljena i ideološki pristrana. Mislim da tvoj pogled kompletno gubi iz perspektive osnovne ideje i ciljeve onoga što je realizirano i mišljeno u samom projektu. Kad čitam ono što pišeš imam osjećaj-iako jesi iz područja, geografskog a mogu reći i ljudskog - da ne znaš, odnosno da nisi jednostavno shvatio što se radilo, što je DeltaLab, što je fakultet, što je birokracija, što je EPK i zašto je proizveden taj specifični rad na toj temi u tom kontekstu.

To su teme koje moraš imati u vidu u trenutku kada počneš pisati, jer moraš znati što gledaš, što kritiziraš, inače je rizik kritike taj da ona postane bespredmetna i ponavljam, ideološki pristrana. Što je veliki problem. Pogotovo za nekoga tko dolazi ne samo iz Rijeke već iz grada kao što je Venecija, škole kao luav, gdje si mogao vidjeti jako puno Biennalea, svijeta uopće, shvatiti izvan hrvatskog konteksta što znači arhitektonska izložba, posao kustosa i dubina i problematika kritike.

Mislim da imaš pravo kod dvije stvari: da katalog još nije izašao (konstitutivni element izložbe), i da je izložba bez vodstva enigmatska. 
Od te kritike ne bježim. Već sam od početka upozoravao na te stvari, ali odlučili smo se za drugačiji put. Mislim da nismo smjeli odugovlačiti i podilaziti specifičnim problemima, ambicijama i željama da se iz kataloga napravi još veća priča... No katalog je taj koji će držati zajedno cijeli kustoski koncept, i jedino on će u budućnosti ostati. Zato i cijela konstrukcija, koja je bila u našim glavama, nije u cjelokupnosti javno deklarirana, nije postala evidentna; manjak tih važnih informacija djelomično je razlog zašto neki nisu u potpunosti razumjeli o čemu je riječ. No, tebi kao autoru članka to ne bi smjelo predstavljati izgovor, ti bi barem trebao o sadržaju razmisliti na artikuliraniji način, oltre la superficie, iako, ponavljam, stvari nisu bile postavljene didaktično. (Usput, koliko kataloga Biennalea imaš kod kuće, koliko si ih prolistao, a koliko si Biennalea podsjetio?)

Koncentrirat ću se samo na par točaka i argumenata u tvome tekstu, koji su za mene ključni, a ima i dosta drugih detalja s kojima se ne slažem, no manje su važnosti i obima, i zato ću ih u ovom kontekstu ignorirati.

„Teme koje utjelovljuju paviljoni-državne granice, luka i željeznica, grad, palače itd. povijesne su naravi i već su gotovo opća mjesta prikaza Rijeke te su puno detaljnije već obrađene u nizu izložbi Muzeja grada Rijeke, ali i unutar novog postava Memorijalnog centra Lipa pamti."

Na predstavljanju izložbe smo rekli više puta-ja prvi-da izložba ne dodaje apsolutno ništa novo povijesnom poznavanju Rijeke. Ali ono što je ključno shvatiti: zašto, poslije cijele serije tih izložba koje navodiš, portala, revija, muzeja, velikih eksperta o svakom fragmentu riječke povijesti, (1) nitko o Rijeci (o arhitektonsko-urbanističkim fenomenima Rijeke, za koje misliš da o njima sve znamo) ne zna ništa u komparativnom kontekstu, odnosno izvan užeg riječkog područja; (2) nitko nije uspio konceptualizirati riječku urbanističku povijest unutar razvoja arhitekture i urbanizma dvadesetog stoljeća općenito; (3) nitko nije pokušao istaknuti unikatne karakteristike ovog grada jednom tematskom, transverzalnom analizom, koja ne pripovijeda samo i isključivo o povijesnim činjenicama jednog specifičnog perioda, već o povijesnom smislu tih činjenica u malkice širem kontekstu od Primorsko-goranske županije, njezinih muzeja i fakulteta, na mjerilu, recimo, cijelog novecenta.

Osnovno pitanje, dragi Mauro, nije to da se povijesno obrađuju fragmenti povijesti Rijeke koju je neko drugi već obradio, već da se vizualizira jedinstvenost Rijeke, da se razotkrije njezina unikatnost u jednom širem kontekstu, za puno širu publiku od specijalista, akademika. I to je već rečeno i prikazano u paviljonu o željeznici Beč-Budimpešta-Rijeka, prvom paviljonu po redu...

Tu se otvara ključni problem, koji tvoja kritika potpuno ignorira: ako sve tako detaljno znamo o Rijeci, kako ti kažeš, zašto unutar arhitektonske i urbanističke povijesti ona ne nalazi svoj smisao, nema nikakvu etabliranu konotaciju? Citirat ću ti tebi dragog Koolhaasa-ne iz Fundamentals-a, za kojeg kažeš da je bio uspješan (ja mislim suprotno, ali o tom potom), već iz Delirious New York-a: kako to da su o NY svi sve znali i znaju, a da se nije nalazio niti u jednoj knjizi o povijesti urbanizma? Osim kao negativni primjer urbane aglomeracije (pročitaj riječi Le Corbusiera, Hilberseimera, Gropiusa o NY)? Kad shvatiš Koolhasovo retroaktivno čitanje New Yorka, shvatit ćeš razliku između povijesti kao faktografije i povijesti koja traži smisao u prošlosti za današnji diskurs. I onda ćeš možda moći shvatiti cilj našeg pokušaja-koji može biti uspješan ili ne s muzejsko-kuratorskog aspekta, ali ga ne možeš jednostavno ignorirati, postavivši limit izložbe u „povjesnu narav” fenomena, koji su bili detaljnije opisani u izložbama u Muzeju grada.

Drugi aspekt, koji nalazim jako problematičnim - i to je, vidim, karakteristika hrvatskog provincijalnog miljea-jest neshvaćanje da povijest nije vlast onih koji se s 
njom bave. Zar ne možemo prihvatiti da Aldo Rossi piše o Dioklecijanovoj palači u Architettura della città? Zar je tako strašno što Le Corbusier analizira osmanlijsku baštinu u Srbiji? Je li tako neprihvatljivo da se Moneo uhvati pričati o Terragniju a da nije nikad bio u arhivu u Comu? Le Corbusierova i Moneova publika je potpuno drugačija od onih povjesničara-među kojima sam i ja-koji pišu kompletno drugoj publici i s drugim ciljevima. Ali mogu ti s velikom sigurnošću reći da Rossijev opis palače, kao i Moneovo čitanje Terragnija, u kontekstu arhitektonske povijesti imaju puno više smisla, kao što se i sam arhitektonsko-urbanistički objekt nadaje puno smislenijim, jačim, aktualnijim iz perspektive današnjih praksi, nego li što su to imaju interpretacije unutar velike većine klasične historiografije. I čudi me da je tebi to danas još uvijek, u Hrvatskoj, neprihvatljivo.

„Osim što fenomenološki pristup naznačen u naslovu izložbe nema uporišta u prikazanoj građi, drugi je propust izložbe ignoriranje recentnijih fenomena grada poput već desetljećima praznih postindustrijskih prostora ili pak transformacije čitavih predjela poput Trsata gdje je prenamjenom vojnog kompleksa početkom 2000-ih nastao studentski grad koji je znatno promijenio društvenu sliku grada."

Na temu fenomenološkog pristupa sam ti već odgovorio, iako ne razumijem zašto on po tvomu mišljenju nema uporišta: na primjer, kada pričamo o prostorima kontinuiteta u vrijeme fašizma i poslije njega, u paviljonu common ground; kako ne vidiš taj fenomen kao inherentnu karakteristiku ovoga grada? Mauro, izvini, ali gdje si ti bio zadnjih pet godina? Izvršeno je sa strane zagrebačkog, beogradskog, ljubljanskog i gradiščanskog fakulteta beskonačno projekata, workshop-a, toliko studija i diploma na temi današnje Rijeke unutar DeltaLab-a (pa i ti si, pobogu, radio na istoj temi)! Ne znam koliko studenata, diplomanata, doktoranada je predstavilo svoje radove na javnim tribinama, izložbama, debatama s gradonačelnicima, međunarodnim gostima, građanima; samo sam ja, koji i nisam izravno sudjelovao u svemu tome, bio sugovornik na barem deset debata-gdje je, ponavljam, DeltaLab bio promotor, a Idis ideator. Imaš članke o tome u Novom Listu, na različitim portalima itd.

O svim stvarima o kojima ti pričaš se uvelike razgovaralo (turizam, baština...) na pojedinim tematskim sastancima: ja sam se osobno svađao sa hoteljerima i investitorima oko projekta obnove hotela Neboder, napadajućii politiku turistifikacije i prenamjene...

Ako već pišeš kritiku o cijelom projektu - od DeltaLab-a preko Fiume Fantastika do ovogodišnjeg paviljona na Biennaleu, koji je još jedan konstitutivni dio cijelog kulturnog projekta (o tom potom) - ne smiješ izostaviti enormni posao koji je uložen u to. Možeš slobodno reći da je posao DeltaLab-a krive prirode, da su problemi drugi, a ne ti s kojima su se studenti bavili, i da smo diskutirali na krivi način. Što bi bilo više nego dobrodošlo. Ali nikako da se tih tema nismo dotakli, jer je to jako neutemeljeno i nepošteno. Radiš iskrivljavanje predmeta koje analiziraš, ignoriraš vrlo važne detalje, baš na onaj način kao što rade tvoji (i moji) politički suparnici.

Ali to da ti ne shvaćaš kontekst izložbe je meni, izvini, neshvatljivo. Mi smo radili izložbu o Rijeci za EPK, predstavljajući taj grad međunarodnoj publici (koja jasno, radi pandemije COVID-a u Rijeku nije došla), unutar DeltaLab-a koji se tim temama posvetio. No, na izložbi tih tema nema jer (1) to nije bio cilj izložbe; (2) o tome smo višestruko već razgovarali u drugim situacijama; (3) publika te izložbe je kompletno drugačija od one gradske, kojima su bile posvećene sve debate prije toga; (4) čitaj niže jer ću se na to vratiti.

(O Trsatu: ja bih te pozvao da živiš pet godina na kampusu, kao što sam učinio ja, pa da se onda vratimo na ovu temu i provjerimo hoćeš li biti istog mišljenja. Ako je ono urbanistička regeneracija društvenog tkiva, onda imamo stvarno drugačiji, 
ako ne dijametralno suprotni pogled na disciplinu urbanizma i arhitekture. Ali to je sada detalj.)

„Sve navedeno dovodi do zaključka da ne bi bilo značajnije razlike da je izložba uprizorena osamdesetih godina prošloga stoljeća!"

Kao prvo, ja sam autor izložbe o recentnoj arhitekturi u Rijeci koja je bila otvorena cijelo vrijeme u Društvu Arhitekata za vrijeme EPK. Kao drugo, Vedran je autor članka o tranziciji u Rijeci, no u katalogu koji još nije izašao. Kao treće, Paviljon na Venecijanskom biennaleu je posvetio rezultatima istraživanja, sintezi-o kojima ćeš prodiskutirati s autorima, jer ja s tim nemam veze. Ali, kako ti nije jasno, tebi koji si lijeve orijentacije, koji si politički aktivan, koji si studirao u Veneciji i radio diplomski rad o Rijeci, da u sklopu jedne ovakve izložbe, koja traži unikatne fenomene riječke povijesti za prikazati međunarodnoj publici, jednostavno nema ništa unikatnoga u Rijeci poslije socijalizma za pokazati? Zar stvarno misliš da je pričati priču-po n-ti put-o turizmu u gradu koji ima $1 \%$ turista Venecije, nešto što možemo tretirati kao jedinstveni fenomen?

Kada pričaš o „bijegu iz zbilje” pomišljaš li da možda realnost jednostavno nije zanimljiva-ponavljam, u kontekstu izložbe, ne DeltaLab-a-da je moraš kontekstualizirati malo šire od same Rijeke, i da u toj rekontekstualizaciji ta naša realnost i nije baš fascinantna, ma rekao bih čak niti posebna. I da-kako je pokazala moja izložba u Društvu arhitekata-današnja arhitektura ne postoji u urbanom tkivu grada. I da živimo u jednom collage cityju bez forme, bez kvalitete. I da jedino ako pogledamo na kolosalne projekte i ideje (austrijske, austrougarske, talijanske, jugoslavenske) možemo shvatiti gdje i kako se u Rijeci radila kvaliteta unutar kvantiteta.

Ja ne bježim iz realnosti, već na nju gledam kritički, i to u širem kontekstu. Ali ne u okviru izložbe Fiume Fantastika, gdje se, ponavljam još jedanput, tražila specifičnost ovog suludog grada. Ne njegova današnja nerelevantnost-jer nema turizma kao u Veneciji, gradske ekonomije i interesa kao u Zagrebu, stanovnika kao u Ljubljani, procentualno romske populacije kao u Beogradu... Rijeka je danas „ništa". A nekad nije bilo tako.

Posao kustosa je taj da stvara koncept izložbe koja će pričati o tako kompleksnoj temi, bez ambicija enciklopedijskog pokrića zbilje: njegov posao je selekcija. Jer, ako nije jasno, izložba se zove Fiume Fantastika, ne Arhitektura Rijeke 1873.-2020.

„Edukacijsko-istraživački centar koji se ugleda na institucije poput moskov- skog instituta Strelka i sada već ugaslog Berlage Instituta u Amsterdamu, čiji je dugogodišnji voditelj Vedran Mimica jedan od suradnika DELTALAB-a, u svojem predstavljanju javnosti, međutim, ni po čemu ne nadilazi programe postojećih regionalnih obrazovnih struktura, nudeći kolegije umjetnosti, povijesti, filozofije i dizajna. Budući da je u međuvremenu osnivanje studija obustavljeno, nije moguće komentirati njegov daljnji razvoj, osim da su kurikulum i osnivanje centra mogli biti znatno progresivniji i kvalitetnije osmišljeni."

Govoriš o DeltaLab-u kao edukacijskom centru, masteru ili postmasteru ili što sve već smo osmišljavali..., tako izrazito ne poznavajući kontekst, hrvatske pravilnike, što je akreditacija i kakvi su zakoni s kojim nastaje jedna škola, da ovo tvoje mišljenje-budući da nije izrečeno u Jutarnjem listu, već u uglednom Životu umjetnosti-kako kažu taljani „rispedisco al mittente” (vraćam pošiljatelju bez otvaranja pisma), pozivajući te da ne otvaraš ovakve teme, u ovom kontekstu, bez da provjeriš osnovne podatke o kojima želiš izraziti svoju kritiku.

Škola se ne radi birokratskim programima, već s ljudima i idejama. Od Bauhausa do Ulma, od luava, Berlagea do DeltaLab-a, kojeg ionako kako je originalno bio osmišljen nećemo nikada vidjeti jer za taj program jednostavno nema novaca. 
„Postavlja se dakle pitanje stvaramo li izložbama poput Fiume Fantastika stvarno korisno znanje koje potiče kritičko razmišljanje i emancipatorske prakse ili reproduciramo postojeće kanone koristeći se spektakularnim dispozitivima koje omogućuje arhitektonsko oblikovanje? I na prvom Venecijanskom bijenalu arhitekture 1980. godine također je u oblikovanju izložbe La strada Novissima upotrijebljen impozantan scenografski postav u postindustrijskom prostoru bivšeg arsenala. Međutim, ono je u ozračju krize, protesta i rasprava 1970-ih godina polemiziralo tadašnji pristup arhitekturi upravo prikazujući projekte pročelja, fasada kao površine na kojima se susreće javni i privatni svijet. lako prvenstveno stilske prirode, izložba je otvorila niz javnih rasprava oko toga čime bi se arhitektura i arhitekti trebali baviti. S vremenom su takve izložbe prerasle u komercijalne sajmove arhitekture, no da je moguće iskoristiti takav format i za sagledavanje sadašnjosti i propitivanje budućnosti pokazalo je 14. izdanje Venecijanskog bijenala 2014. godine all star arhitekta Rema Koolhaasa. Njegovo kuriranje međunarodne izložbe vođeno s jedne strane kroz povijesno obračunavanje s projektom modernizacije na globalnoj razini, a s druge upravo kroz fenomenološki pristup u detektiranju europskih prostornih i društvenih nejednakosti na primjeru Italije, pokazalo se vrlo uspješnim."

Ja mogu shvatiti osnovno pitanje koje postavljaš o korisnosti znanja, i za to imam odgovor koji je jako osoban. Znanje je intelektualni konstrukt, koji se zasniva na selekciji problema i teza. Ja stojim iza mojih, u dobru i zlu; moja akcija u difuziji znanja možda nije korisna, ali prihvaćam taj izazov, sa svim svojim greškama i mogućim iluzijama. I slobodno stoj protiv moje ideje. I nju kritiziraj. Ali molim te, nemoj mi citirati Portoghesijev Biennale.

Je li stvarno znaš što je taj Biennale bio? Pa to je početak kraja, dragi Mauro, gdje su si akademski arhitekti dali važnost, legitimitet da iskažu kako se ispred krute realnosti treba vratiti u autonomiju arhitekture, i da samo fasada-izgled, odnosno forma u najbanalnijem i najvulgarnijem smislu-nosi vrijednost arhitekture. Pa ti bi trebao biti radikalno protiv te ideje, ta kritika bi trebala biti u srcu tvojeg antineoliberalizma, iako je rehabilitacija Portoghesija danas (za mene više nego problematično) u modi: Portoghesijev Biennale je početak star-sistema, to je početak onoga što živimo danas, to je legitimiziralo umjetničku pasivnost jednog aristokratskog i ekskluzivnog pogleda na arhitekturu. Kakve veze ima La presenza del passato s Fiume Fantastika? Pa je li moguće da ne vidiš razliku između aristokratske operacije jednog senilnog akademika koji traži autolegitimitet i jedne banalne ideje FF da se postave paviljoni (a ne fasade) unutar industrijskog objekta da simuliraju korzo? Pa je li moguće da nisi vidio niti jednu drugu arhitektonsku izložbu s paviljonima unutar jednog već postojećeg prostora, s kojom bi mogao povući poveznicu?

I ti, koji citiraš Koolhaasa, kao primjer propitivanja sadašnjosti, je li doista moguće da ne citiraš Fundamentals? Pa to je deklaracija kraja arhitekture kao kritičke discipline. Ili se ne slažemo da je prefabrikacija i generičnost kao budućnost jedan statement o definitivnoj smrti lokalizma, partikularizma, specifičnosti, originalnosti? Je li stvarno stojiš iza toga? Ti, sa svojim političkim idejama i svojim kritikama ne vidiš da je baš Koolhaas taj koji predstavlja - na intelektualnom i idealnom nivou -tvojeg neprijatelja? Pročitaj moj članak u Orisu o njegovoj intervenciji u Veneciji: moja kritika je oštra, i za razliku od tvoje utemeljena, poznavajući sve okolnosti. I nemojmo se sakrivati iza Absorbing modernity, koja nije njegov produkt, već „naš", i to jako dobro znaš jer si u njemu sudjelovao.

„Sve to ostavlja pomalo gorak okus propuštene prilike. Ne samo u sklopu programa prijestolnice kulture nego i inače, kritičko promišljanje prostora trebalo bi biti osnova za stvaranje novog urbaniteta, međutim izložba Fiume Fantastika nije pružila suočavanje sa surovom urbanom stvarnošću pa prema tome ni moguće vizije budućnosti. Vakuum koji nastaje takvim pristupom višestruko je štetan, osim zbog 
očitog nedostatka kritičke prostorne svijesti ovdje i sada, i zbog nerealiziranog transfera znanja, iskustva i ambicije na mlađe generacije arhitekata i istraživača."

Citirat ću Minu, koju vjerojatno poznaješ: „Parole, parole, parole“. Nije riječ u tvojem članku o EPK, o ekonomskoj i pandemijskoj situaciji kroz koje je taj projekt prošao kroz 2020. Niti je riječ o tome da je jedina međunarodno relevantna arhitektonska izložba koja je bila producirana u Rijeci-FF. Niti je riječ o tome da ne postoji grad u Hrvatskoj koji u zadnjih pet godina nije toliko razmišljao o svojoj budućnosti kao Rijeka, zahvaljujući prvenstveno DeltaLab-u, koji je bio promotor svega toga. Niti je riječ o politici, odnosno o promašenom dijalogu između inicijative arhitekata i povjesničara (DeltaLab) i politike. Mi nismo aktivisti, dragi Mauro, ali ne mora značiti da nismo razmišljali i ukazivali na probleme, kamo treba ići, što je realnost, koje su moguće smjernice. Niti je riječ s tvoje strane o tome da možda naša struka, kroz primjer EPK i FF, ipak prikazuje da mi više nemamo nikakvog smisla u realnosti, u promjeni arhitektonske i urbanističke zbilje-ne zato što smo glupi, nesposobni, nedovoljno aktivni. Već zato jer odluke već odavno ne prolaze kroz naše ruke, koliko god mi govorili i urlali, već po smjernicama koje idu daleko izvan Obersnelove kancelarije ili HDZ-a u Zagrebu.

Jako je neistinito-i neodgovorno s tvoje strane-da optužuješ projekt i istraživanje radi „nerealiziranog transfera znanja, iskustva i ambicije na mlađe generacije arhitekata i istraživača". Dragi Mauro, još jedanput ponavljam desetine i desetine diplomskih radova, workshop-a-zadnja diplomska radnja koja se je bavila s temom Rijeke je ona mladog Davida Naglića na milanskoj Politehnici, koju je s velikim zanimanjem mentorirala Kazuyo Sejima. Dodajem seriju multidisciplinarnih diskusija i konfrontacija o svim ovim temama-unutar DeltaLab-a-koje su kreirale grupu ljudi (tvojih vršnjaka) koji su izašli na lokalne izbore i osvojili zavidne postotke u gradskoj skupštini. To nije za tebe transfer ideja i iskustva? To nisu mladi ljudi? To nije kritičko razmišljanje?

Lako je reći da je izložba propuštena prilika. Ali vrlo je teško to pošteno kontekstualizirati, dokazati, artikulirati. Generalne riječi nisu dovoljne. I baš radi toga jer su tvoje riječi teške, imaju odgovornost da se suoče s nečim što nisi, moram reći, ni u jednoj rečenici dohvatio - a to je dubina problema. Zato sam i napisao ovo, ne zato jer me smetaju kritike. Smeta me njihova površnost. 
